\title{
Diversity in the workplace: an overview of disability employment disclosures among UK firms
}

Article

Accepted Version

Khan, N., Korac-Kakabadse, N., Skouloudis, A. and

Dimopoulos, A. (2019) Diversity in the workplace: an overview of disability employment disclosures among UK firms.

Corporate Social Responsibility and Environmental

Management, 26 (1). pp. 170-185. ISSN 1535-3966 doi:

https://doi.org/10.1002/csr.1669 Available at

https://centaur.reading.ac.uk/79124/

It is advisable to refer to the publisher's version if you intend to cite from the work. See Guidance on citing.

To link to this article DOI: http://dx.doi.org/10.1002/csr.1669

Publisher: Wiley

All outputs in CentAUR are protected by Intellectual Property Rights law, including copyright law. Copyright and IPR is retained by the creators or other copyright holders. Terms and conditions for use of this material are defined in the End User Agreement. 


\section{CentAUR}

Central Archive at the University of Reading

Reading's research outputs online 
Diversity disclosure reporting on people with disabilities by U.K. firms

\author{
(C) Dr. Nadeem Khan \\ nadeem.khan@henley.ac.uk \\ Lecturer in Governance, Policy and Leadership \\ Greenlands Campus \\ Henley Business School, UoR \\ Henley on Thames \\ Oxfordshire RG9 3AU \\ UK \\ (C) Dr. Antonis Skouloudis \\ a.skouloudis@henley.ac.uk \\ Lecturer in Reputation and Responsibility \\ Greenlands Campus \\ Henley Business School, UoR \\ Henley on Thames \\ Oxfordshire RG9 3AU \\ UK \\ (C) Prof. Nada Korac-Kakabadse \\ n.kakabadse@henely.ac.uk \\ Professor of Policy, Governance and Ethics \\ Greenlands Campus \\ Henley Business School, UoR \\ Henley on Thames \\ Oxfordshire RG9 3AU \\ UK \\ Dr. Andreas Dimopoulos \\ (C) Andreas.Dimopoulos@brunel.ac.uk \\ Lecturer in Law \\ Disability Tutor \& Reading Group Co-ordinator \\ Brunel University \\ Kingston Lane, Uxbridge \\ Middlesex UB8 3PH \\ UK
}

\begin{abstract}
People with disabilities (PWD) have been defined as the world's largest minority group. This societal group continues to face significant barriers to labor market entry and social inclusion. The associated costs to supporting non-working PWDs can be
\end{abstract}


high and long term. Yet, their potential as motivation, contribution and impact to human capital, adaptability, firm productivity and the innovative capacity of business entities is valuable and underutilised. PWD employment is a pressing 'advanced market' issue with strong implications on the nature of equitable opportunities, social mobility and diversity in the workplace. A better level of responsiveness by firms is needed to endorse enabling conditions towards broader social sustainability and as impact on PWDs quality of life.

This study attempts to assess the quality of corporate reporting disclosure on disability issues by U.K. firms, as a stepping stone for mainstreaming integration of PWDs into labor markets under the scope of corporate social accountability. The information published in 274 sustainability reports highlights trends pertaining to disability employment. We benchmark U.K. sustainability reports against PWDadapted indicators of the Global Reporting Initiative guidelines. Findings suggest that U.K. corporate disclosures on PWD employment are lacking in key respects, leaving much to be desired, and with plenty of room for improvement in order to clearly set out their commitment in favor of PWD employment. Drawing on these findings, implications for PWD employee policy and practice are outlined.

Keywords: People with Disability; employment; firm reporting-disclosure; social sustainability; United Kingdom.

\section{Introduction}

Almost $15 \%$ of humanity is living with a disability (WHO, 2011). This has been increasing with the combined effects of growing global population and extended life- 
expectancies. Disability survival rates and quality of life are being affected by medical and technological advancements, genetics, food-chain and societal or environmental events. An overall increase of 5\% since the 1970 s, translates to more than one billion people having 'long-term physical, mental, intellectual or sensory impairments which in interaction with various barriers may hinder their full and effective participation in society on an equal basis with others' (U.N., 2006).

People with disability/-ies (henceforth PWD) are often characterized as the world's largest minority group whose rights are often discounted and may be discriminated (Quinn, 2009). Whilst 80\% of PWDs live in developing countries (World Bank, 2018) and $20 \%$ of the poorest people have a disability (Disabled World, 2018), it is common across economic and cultural norms that PWDs remain highly vulnerable regardless of whether the Nation adopts an individual or social governance model (Oliver, 1966, Priestley, 1998). Women and children PWD life opportunities have remained lowest across many countries (OECD, 2010).

Overall, only 45 countries have anti-discriminatory regulation and disability employment laws. In the U.S. and many European countries the PWD employment rate gap varies as much as $40 \%$ compared to people without limitations (U.K., Hungary, Netherlands, Romania) and it is higher in other countries e.g. Peru (U.N., 2017). In Turkey, Luxembourg and Greece PWD employment rates are comparatively better. Even within the most highly educated and regulated nations (Priestley, 2007) the adoption of terms such as equal opportunities, human rights or diversity and inclusion by organizational systems and processes may represent deterioration from the expected goals or social desires indicating failed organizational change (Tatli, 
2011, Cannon and Edmunson, 2001) or corporate governance deviance (Aguilera, Judge and Terjesen, 2018). The gap between policy design and firm implementation persists as PWDs face significant barriers to entry in their labor markets (Kulkarni and Lengnick-Hall, 2014).

The U.K. has been a signatory of the United Nations Convention on the Rights of Persons with Disabilities (CRPD) since 2009 and has recently been criticized for not supporting people to lead independent lives (Lambert, 2017). In the U.K. there are more than $4 \mathrm{~m}$ people with disabilities of working age i.e. 16-64 (Papworth Trust, 2016 ${ }^{1}$; Disabled Living Foundation, 2017) of which 2.4m claim Employment Support Allowance (ESA) benefits (Vale, 2018). The government has pledged to increase disability employment by 1 million over the next ten years (Brown and Powell, 2018). The prevalence of disabled people increases with age i.e. $7 \%$ children; $16 \%$ working age; $43 \%$ elderly. This alerts to social inclusion better transitioning from institutional to firm policy and practices in demonstrating diversity in the workplace (Ariss et al., 2012; Tatli and Ozbilgin, 2009).

PWDs assert that discrimination and poverty issues are of particular concern to members of their minority group ${ }^{2}$. Disabled people are more likely to face discrimination at a young age, in schooling, and may leave education earlier compared to non-disabled peers (OECD, 2012). This becomes a further disadvantage when competing to enter employment and gain work experience. Research confirms

\footnotetext{
${ }^{1}$ There are more $11 \mathrm{~m}$ disabled people in U.K. and the employment gap is $44 \%$ to $84 \%$ (2016). $44 \%$ of disabled people are economically inactive.

${ }^{1}$ http://www.theguardian.com/global-development-professionals-network/2016/jun/23/disabled-people-growincreasingly-frustrated-at-being-denied-the-chance-to-work
} 
that the disability itself may also hinder promotional chances and that PWD employees are often the first to be laid off in times of recession, or more likely to experience rock bottom (Shepherd and Williams, 2018) compared to non-disabled workers (Kaye, 2010).

The focus of this paper examines opportunities to better address the most commonly stated issue by PWDs in the U.K. as firm barriers to employment (43\%). We take a firm perspective to highlight opportunities for encouraging and sustaining PWD employment. The rest of the paper is structured as follows. The next section brings to attention firm diversity and PWD employability. This is followed by an overview of institutional arrangements for PWD rights and public reporting by firms on PWD issues. We introduce stakeholder theoretical framework for firm understanding of PWDs before outlining the research approach and identifying the sample for our study. The findings are presented ahead of a discussion, including implications for firm policy-design and practice.

\section{Firm diversity and PWD employability}

Firm diversity as an employability issue has been investigated as single level studies from firm process (French, 2001; Ryan and Haslam, 2009) and individual employee (Cornelius and Skinner, 2008) perspectives. Meanwhile, multi-level diversity studies give priority to other stakeholder pressures (Zannoni and Jannessons, 2007). Typically corporate responsibility agendas aim at corporate image protection and reputation enhancement rather than genuine commitment to PWD employment (Segovia-San-Juan et al. (2017). The firm emphasis is usually on social and cause 
related marketing activities to support PWDs (Min-Young et al., 2009; Peloza and Shang, 2011; Vauclair and Fischer, 2011) as critical for firm social acceptability (Klarsfeld, Ng, Tatli, 2012). But such actions from 'benevolent companies' are deemed to be insufficient as they keep PWDs at a distance and limit the possibility of integrating them into the value chain of an enterprise (González and Fernández, 2016).

The U.K. being an advanced governance market is unique in its neo-liberal economic and historical social benefits model (Ozbilgin and Tatli, 2011). Yet, there remains very limited research pertaining to corporate disclosure on PWD employment and examining the voluntary reporting practices by U.K. firms on PWD employment. Our study seeks to address this inadequate 'functional diversity' (Romañach and Lobato, 2005).

PWDs are often in a unique position to enhance human capital contribution within business entities (Konrad et al., 2012). They can have more specialized and refined skill sets e.g. numerical, memorization, attention to detail, higher IQ (Hashim and Wok, 2014). The call remains for firm practices to be more accommodating of individual's needs such as autism, dyslexia, stamina, mental, physical or sensory impairments throughout their recruitment, selection, settling in and longer term integration processes for PWDs (Schur, Kruse and Blanck, 2005).

This may include more flexible timings, managing work load, greater care in team working and higher tolerances for emotional or physical constraints (Mackelprang and Salsgiver, 2016; Bruyere, 2000). To exemplify, tasks such as getting dressed in the morning or travelling into work can take longer for PWDs. The spirit of diversity 
places an inclusive responsibility on the firm ${ }^{3}$ to go beyond legal conformance to changing group-thinking, firm culture and narrow perceptions of acceptable business practices (Oreg et al., 2018). Thereby, PWDs become recognized as human resources of creativity, unique skills, innovative ideas and talent (Hernandez et al., 2008; Buciuniene and Kazlauskaite, 2010; Hashim and Wok, 2014).

The significant advancements in science, technology, architectural and ergonomic design support enhancing opportunities for PWDs skills and competencies to make more effective work contributions (Perez et al., 2017; Barnes and Mercer, 2005). Empirical findings suggest that employees with special needs exhibit higher levels of motivation, productivity, job retention and lower occupational accident rates compared to employees without special needs (Bradshaw, 2004; Markel and Barkley, 2009; ILO, 2010; Hartnett et al., 2011; Houtenville and Kalargyrou, 2012). PWD employment is not simply a pressing economic concern, but has deeper and more complex cultural and value stakeholder implications that emerge in corporate social responsiveness and sustainability agendas of firms (Markel and Barkley, 2009; Samant et al., 2009; Kuznetsova and Yalcin, 2017; Waxman, 2017; Williams, 2017).

\section{Institutional arrangements: PWD rights and the case of U.K.}

An array of international norms and standards on human rights protection delineate PWD rights. Being the most significant one, the UN Convention on the Rights of Persons with Disabilities - CRPD (U.N., 2006) sets forth PWD rights around eight

\footnotetext{
${ }^{3}$ Firms are being encouraged to sign up to the Disability Confident Scheme in U.K..
} 
fundamental principles, such as dignity, accessibility and equal participation and inclusion (Art. 3 CRPD). Art. 4 CRDP reflects general obligations for governmental bodies, which extend to organizations of the private sector. For example, states parties to the CRPD must take all appropriate measures to eliminate discrimination on the basis of disability by any person, organization or private enterprise (Art. 4(e) CRPD). The CRPD introduces a different approach to disability issues, which is based on the social model of disability. In essence, this considers that disability is the product of negative social attitudes and/or external (usually architectural) barriers, which preclude PWD from participating equally in social and economic life. Measures such as accessibility standards for public transport, or reasonable accommodation offered to PWD as employees, enable PWD to enjoy their human rights on an equal basis with others (Kayess, 2008).

Several CRPD rights have a direct bearing on the issue of disability employment, as well as disability employment disclosure. Art. 27 CRPD protects the right of PWD to gain a living by work, freely chosen or accepted in a labor market and in a work environment that is open, inclusive and accessible. Art. 27 CRPD details an indicative list of measures to implement the right to work for PWDs. Chief among these is the prohibition of discrimination, equal opportunities for work and pay, and reasonable accommodations. CSR with regards to PWD must be guided by the CRPD, and PWD employment disclosure must provide details on how businesses comply with Art. 27 CRPD. This approach is strengthened by Art. 31 CRPD, which places an obligation on states to collect appropriate information, including statistical and research data, to enable them to formulate and implement policies to give effect to CRPD rights. PWD 
employment disclosure data are therefore of critical importance for protecting Art. 27 CRPD, because they provide vital information with regards to the right to work for PWD is protected. In this sense, PWD employment disclosure is not only a CSR issue, but also a CRPD issue. Under Art. 31 CPD, PWD employment disclosure must provide adequate and detailed data on all the aspects of Art. 27 CRPD.

It is clear that international human rights law provides robust protection to the right of PWD to work. Even though several international law or E.U. policy documents aim to foster the right to work for PWDs, the protection afforded by the CRPD is more complete (Fasciglione, 2015). As mentioned, Art. 27 CRPD protects equal access to the labor market, and also affords protection to PWD during employment. Similarly, an integral part of effective protection is Art. 31 CRPD on data collection. Given the prominence of the CRPD for protecting the human rights of PWD, it follows that CSR with regards to the employment of PWD must be based on the particular elements of Art. 27 CRPD, and disability employment disclosure must provide full and accurate data to measure the implementation of the right to work under Art. 27 CRPD.

Likewise, the U.N. Guiding Principles on Business and Human Rights (UNHRC, 2011) outline business responsibilities on human rights throughout their operation and networks, indicate appropriate measures to assess human rights protection, including PWD rights, and suggest relevant external reporting processes. In Europe, the European Disability Strategy $2010-2020$ is built around eight priority areas that aim to promote an inclusive society and business opportunities from products and services accessible to all. Over the past decade, European countries have started to promote more actively the integration of PWDs in labor markets and placed increased 
emphasis on the stronger involvement of the private sector (OECD, 2010). Disability is promoted as an emerging investment priority through the European Structural and Investment Funds 2014- 2020 with the business sector being in a unique position to actively promote PWD rights. By embedding such rights into business models, businesses can potentially shape new and hard-to-imitate competitive advantages and achieve enabling conditions for 'inclusive growth' in line with the EU 2020 strategy (EC, 2010). In 2014, the Council of the European Union introduced a Directive on the disclosure of non-financial and diversity information by large corporations with the aim of enhancing the transparency and accountability of 6,000 business entities with more than 500 E.U. employees. With Member-States having two years to transpose it into national legislation, the first company reports will be published in 2018 .

In the U.K., the Independent Living Strategy (Office for Disability Issues, 2008) pinpointed actions required to ameliorate PWDs quality of life through better access to education, employment and to participation in community life among other parameters. The U.K. has combination of legislation and high societal awareness that drives increasing stakeholder expectations as well as upholding and evolving the country's anti-discrimination legislation (Habisch et al., 2005; Samoy, 2010). The Equality Act 2010 underpins PWD rights against employers' discrimination and sets forth requirements on workplace adjustments that employers need to attend (Sainsbury, 2011). In this respect, the Roadmap 2025 published by the Office for Disability Issues (2009), sets out the ambitious vision and strategic perspectives of the U.K. government to achieve disability equality by 2025 under the scope of 14 critical themes where appropriate arrangements can have drastic improvements in PWD well- 
being. These policies on disability however, have to be understood in the wider context of protecting disability rights in the U.K. In October 2017, the CRDP Committee issued its concluding observations on the Initial Report of the U.K. concerning the implementation of the CRPD. In relation to the right to employment, the Committee expressed its concerns, amongst other things, about 'the persistent employment gap and pay gap for work of equal value affecting persons with disabilities...', as well as the insufficient affirmative action measures and provision of reasonable accommodation to ensure that persons with disabilities can access employment on the open labour market, despite the obligations contained in European Union Directive 2000/78/EC on non-discrimination in the workplace (CRPD Committee, 2017). In this sense, despite any positive steps in ensuring accessibility to employment for persons with disabilities, it seems clear that difficulties still persist.

This raises questions in terms of how is law and regulation influencing firm practices in reality? What are the governance and practical issues e.g. social security and benefits, HR practices, in firm attitudes? Why are PWD concerns not being appropriately addressed? What impact is firm reporting on PWDs having towards integration of PWDs into long term firm employment?

\section{Public reporting by firms on PWDs}

Using cross-sectional data from sustainability reports, the European Network for Corporate Social Responsibility and Disability (CSR+D, 2012) provides an outlook on disability issues disclosed by corporations actively engaged in PWD issues and best-in-class sustainability reporters (Table 1 below). Their findings denote that 
among the 16 companies selected: a) $31 \%$ disclose quantitative information on PWD workforce (in either absolute, percentage or relative figures), yet, the data does not always point out trends over time or reference to compliance with laws; b) $25 \%$ explicitly state the critical importance of diversity (including aspects of disability) within their workforce; and c) $44 \%$ report on training programmes, focus groups or workshops in place in order to promote increasing awareness of their managers as well as the integration of PWD employees.

Cordero et al. (2014) conduct a quantitative content analysis of PWD employmentrelated issues reported by $40 \mathrm{MNCs}$ combined with qualitative data from experts' input. Their findings reveal that disability disclosures in sustainability reports leave much to be desired: it is less than half of the sample firms that provide data on PWD workforce or a comprehensive strategy towards PWD employment, while, strikingly, enterprises actively engaged in addressing disability do not report on the related initiatives they endorse.

Finally, the Global Reporting Initiative (2015) provides a guide to firms seeking to Commented [WU1]: Segovia-San-Juan et al. (2017) see table 1 better understand the business value of disability and effectively communicate their commitment to respecting PWD rights. Their report offers best-practices examples from large corporations around the world as well as practical guidance on how to effectively report on a number of critical disability-related matters.

(Insert Table 1 here )

\section{Conceptual framework: DWPs as firm stakeholder}


Theoretical underpinnings of corporate PWD reporting include stakeholder and more widely legitimacy conceptual frameworks.

Stakeholder theory posits that all business entities are affected by as well as affect various social constituents that they engage with (Freeman, 1984; Donaldson and Preston, 1995). Such nexus of relationships justifies a fruitful management of stakeholder demands or claims, beyond mere shareholder value maximization objectives and towards a broader balancing of the more diverse set of stakeholder expectations (Goodpaster, 1991; Frooman, 1999). Stakeholder management (Freeman, 1984) set forth approaches for the identification of critical-for-the-firm stakeholder groups ${ }^{4}$ that require adequate attention and effective channels of dialogue. From the stakeholder perspective, PWD disclosure serves as an instrument of meaningful communication and engagement between the reporting entity and PWDspecific social constituents. It can constitute an effective instrument for the more primary negotiation of firm-PWD relationship which seems currently a higher priority for the minority group (see Roberts, 1992).

Strongly intertwined with social accounting and reporting, legitimacy theory places business activity within the broader social system and stresses the need to conform to societal norms and expectations. According to Suchman (1995) the notion of legitimacy reflects "a generalised perception or assumption that the actions of an entity are desirable, proper, or appropriate within some socially constructed system of norms, values, beliefs, and definitions” (p.574). Such legitimacy 'lens' of analysis sets

${ }^{4}$ Primary stakeholders have direct relationship with firm and Secondary stakeholders have indirect relationship. Are PWDs primary for the firm? as much as firm employment is for PWDs? 
forth a broader form of 'social contract' between business and society. Society supplies firms with a diverse set of skills and resources to conduct their for-profit activities, in return for socially-accepted (i.e. legitimate) business behaviour (Mathews, 1993; Deegan, 2002). In this respect, PWD disclosure (as part of the organizational reporting channels) can be a fruitful legitimisation instrument used to signal to society that the reporting entity is in line with social norms and expectations while seeking to achieve (at least) socially-benign performance (Lindblom, 1994).

Stakeholder theory offers a focused framework to better understanding of the firm perspective in giving priority to PWDs and is our theoretical lens. More broadly, our study may further contribute towards legitimacy theory in the wider understanding of social acceptability as business-society relations.

\section{Research approach and sample}

The meaningful voluntary disclosure of disability issues through corporate media and reporting channels potentially provides a stepping stone for mainstreaming integration of PWDs into labor markets and in consolidating social inclusion under the scope of an equal opportunities for more equitable and fairer society (Papworth Trust, 2016; CSR+D, 2012). Relevant management and performance specific information can assist in highlighting best practices, prioritizing needs and facilitating the appraisal of relevant policies, plans and initiatives that are already in place. At the highest level, international multi-stakeholder organizations such as the Global Reporting Initiative (GRI) and the World Business Council for Sustainable Development (WBCSD) are making substantial effort in this direction. They 
encourage business entities to publicly report on their human rights impacts through their sphere of influence, including endorsing diversity in the workplace through disclosure of quantitative and qualitative indicators covering disability-related matters.

This study seeks to reveal gaps and trends in corporate disclosures on PWD employment and evidence whether and how aspects of disability are mainstreamed through the discourse of leading business entities. Focusing on the U.K. business sector, we examine publically published sustainability reports during $2016(\mathrm{n}=274)$. The disability-adapted indicators of the Global Reporting Initiative G4 (GRI-G4) guidelines are employed, utilizing a numerical scoring system. Taking into consideration that the corporate social responsibility and disability literature is still sparse, the paper paves the way for a more systematic empirical investigation of PWD within the enterprise, its reporting (i.e. stakeholder engagement) channels, and how such social sustainability perspectives are materialized through the CSR agenda.

\section{Method and analysis}

Voluntary disclosure on disability employment was assessed utilizing excerpts from the Global Reporting Initiative (GRI-G4) sustainability reporting guidelines. GRI has been a primary mover of voluntary disclosure on organizational sustainability issues including human rights protection and non-discrimination in the workplace. The GRI-G4 guidelines include a stand-alone section of reporting requirements on diversity and equal opportunity consisting of: (i) the disclosure of the reporting entity's management approach on the specific issue and (ii) quantitative 
information regarding the composition of governance bodies and workforce per employee category according to indicators of diversity (gender, age, minority groups, etc.). These aspects describing an inclusive work environment were adapted to assess management mechanisms and policies in place as well as absolute and relative figures of disability employees within the enterprise (Table 1 ).

\section{(Insert Table 2 here)}

We focused on the sustainability reports as they have emerged in the past few years as the new "business card" of a company, incorporating critical aspects of nonfinancial performance in a stand-alone document. A web-based search was conducted between September and December 2016 in order to gather the latest reports published by U.K. companies (i.e. for the reporting period of 2015). We relied on the GRI database (database.globalreporting.org) where business organizations are invited to voluntarily subscribe and submit their sustainability/nonfinancial reports and, in total, 274 U.K. reports were collected which comprised the sample for analysis.

A five-scale grading scheme for the two aforementioned categories was employed on the basis of information quality and comprehensiveness. Non-disclosure equals to a zero score, fuzzy-brief statements are assigned 1 point; coherent yet limited coverage receives 2 points; extensive and systematic-'full' disclosures (i.e. in terms of consistent and concise of GRI requirements) are assigned 3 and 4 points respectively. The assessment includes cross-references to other corporate communication channels 
and publications only when specific web links or other publicly available information were denoted in the report. Likewise, information pertaining to non-discrimination and/or employee diversity without explicit reference to disability perspectives have not been taken into account in the assessment, as it is unclear to conclude whether the reporting entities of such disclosures demonstrate a clear commitment to employing PWDs.

A selection of quotations is included in the presentation of findings (see table 6), in an attempt to illustrate the corporate discourse of PWD employment. While generalizations with regards to reported information are pointed out in the following section, impressions such as 'sample companies tend to', 'few of the assessed firms' or 'the majority of sustainability reports' are used when more (less) than $50 \%$ the sample firms reports in a similar manner.

\section{Findings}

Findings reveal that voluntary disclosure on the employment of people with disabilities leaves is varied and leaves much to be desired. It is not clear whether most sample firms are strongly committed to employing people with disabilities and a 'disability-confident' work environment. Most reports fail to provide a comprehensive (i.e. strategic) implementation plan for recruitment, promotion and retention of disability employees. They tend to retain a rather 'commercial' posture on disability, emphasizing internal awareness-raising initiatives and charitable contributions related to disability causes, while lacking descriptive (roles, functions, levels of responsibility, level of education and job profile of disability employees) and 
quantitative (aggregated data and disaggregated by type of contract, disability, gender or other firm-specific criteria) metrics to allow stakeholders to assess organizational performance on disability and facilitate decision-making processes. Regardless the type or level of coverage of inclusion policies and mechanisms in place, it is 175 companies $(64 \%)$ that provide information in qualitative and/or quantitative terms. These 175 reporting entities are broken down by industry and size in Tables 2 and 3 Commented [WU3]: Should this be 3 and 4 ? Introduce below and presented in Figures 1 and 2 respectively.

\section{(Insert Tables 3-4here)}

Companies pertaining to financial services sectors and other services industries (mention few of those here...) represent $17 \%$ of the reporting entities; all other industries comprise less than $10 \%$ of sample firms. Likewise, large firms are the majority of those providing information on disability employment (116 firms; 66\%), followed by MNEs (57 corporations; 33\%) and a mere 1\% are SMEs (2 enterprises).

\section{(Insert Figures 1-2 here)}

Disclosure of management approach and policies, plans or programmes in place in order to address disability employment is mostly brief and pertains to vague statements. This is mainly communicated through fragmentary references to disability incorporated in sections of the report discussing the promotion of diversity, non- 
discrimination and equal opportunities in the workplace. "We aim to build a diverse and inclusive workforce ensuring there are equal opportunities and no discrimination in terms of race, gender, age, marital status, sexual orientation, religious beliefs or disability" is a catch-all phrase commonly found in most reports.

Indeed, while diversity tends to be pinpointed as an important aspect of organizational culture, recruitment of people with disabilities is seldom identified as a critical parameter defining core values and sustaining social inclusion. Only 10 reports extend such statements to clarify their management approach to disability employment while a mere $2 \%$ (five large corporations) dedicate a notable part in the report to providing extensive information on their approach and policy to endorse and monitor the employment of people with disabilities within the organization and its entire value chain (suppliers and related partners).

For instance, BT Group and Carillion ${ }^{5}$ point out the Two Ticks disability stamp received from the U.K. Government, reflecting five commitments to being a fair employer to those with disabilities, with the latter to indicate a target of $10 \%$ 'hard-toreach' groups $^{6}$ to develop skills in order to enter employment (Carillion Plc Sustainability report, 2015). GlaxoSmithKline (GSK) partnered with the U.K. Government's Disability Confident campaign to raise disability awareness across the company, remove barriers and ensure that people with disabilities have adequate

\footnotetext{
${ }^{5}$ Carillion has collapsed in January 2018 and puts a focus on U.K. PFI outsourcing model of Public contracts to private sector firms see https://www.ft.com/content/8763b88c-fd11-11e7-a4922c9be7f3120a

${ }^{6}$ Carillion defines as 'hard-to-reach' those social groups with either real or perceived barriers to employment.
} 
opportunities. Moreover, GSK promotes disability employment of veterans in small businesses pertaining to its supply network through diversity programmes (GlaxoSmithKline, Responsible Business Supplement 2015). Likewise, in collaboration with social enterprise 'business disability international', GSK assesses its disability performance utilizing a set of well-established global standards.

(Insert Tables 5-6 \& Figure 3 here...) introduce tables above?)

Employment data on disability among U.K. reporters is scarce. Companies tend to place more emphasis on diversity indicators in terms of gender and race in top and/or middle management positions as well as the general workforce compared to disability employees within the enterprise and its sphere of influence (i.e. suppliers and corporate partners). More than $92 \%$ of sample reports (pertaining to 253 large and multinational enterprises) do not disclose relative information while a mere $4 \%$ and $3 \%$ disclose either brief statements or aggregated data respectively. Comprehensive disclosure in terms of GRI requirements and/or linking data with specific targets is provided by only three firms ( $1 \%$ of sample firms). Likewise, it is only $1 \%$ that

Commented [WU5]: Do we know which ones. i.e... reports on trends over a time series regarding the share of employees with disabilities in the total workforce figures. Armor Group is one of the very few companies in our sample providing data on employees with disabilities (i.e. $2.4 \%$ of the Group's workforce; down by $10 \%$ in comparison with the previous year's figures). Sky discloses the relative and absolute number of disabled employees for the previous and the reporting period in reference. Similarly, PayPoint and BT Group provide the 
relative number of employees with disabilities with the latter providing data for a timeline (2011-2015) and broken down between managerial and non-managerial (team) members. Providence Financial reports on the percentage of disabled employees and compares it with the respective national average figures. Crossrail benchmarks its performance on disabled employees against the national Contractors' Group industry data (UKCG) including the performance of the company's contractors and supply chain partners.

(Insert Table 7-8 \& Figure 4 here)...introduce tables?

\section{Discussion}

This study's findings contribute to the very limited research in accounting of and reporting on the employment of people with disabilities as an aspect of social sustainability and social inclusion. The findings suggest an effectiveness deficit by U.K. private sector firms towards this minority stakeholder group (and all interested social constituents) remains. The lack of good quality evidences and longitudinal progression towards change by the firm hampers fruitful firm-PWD stakeholder engagement.

Furthermore, the study demonstrates that there is a noticeable gap between the demands of disability rights under CRPD and the way that disability employment disclosure, and firm CSR agendas, are being understood with regards to persons with disability. As early as 2012, the U.N. Report: 'Corporate Responsibility to Protect Human Rights' acknowledged that businesses must respect human rights, such as the 
International Bill of Human Rights. The Report argues that businesses may have to follow additional human rights standards, if their activities may pose a risk to the rights of individuals belonging to specific groups or populations that require special attention - such as persons with disabilities.

Our study indicates that policy implications of CRPD rights with regards to CSR extend beyond the remit of Art. 27 that refers to the right to employment, including disability employment disclosure. This is because Art. 31 CRPD requires states to collect appropriate information, including statistical and research-based data, to enable them to formulate and implement policies that will give effect to CRPD rights.

In this sense, the foremost policy implication of CRPD rights is that disability employment disclosure must provide far more detailed data with regards to business compliance with crucial aspects of Art. 27 CRPD. A second policy implication is that CSR with regards to disability employment must more explicitly respect Art. 27 CRPD. Thus, the disability-related indicators of the GRI guidelines (GRI-G4) must align to the content of Art. 27 CRPD. In the absence, as yet, of a general comment on the right to employment by the CRPD Committee, the business sector should follow more closely the interpretation of Art. 27 in each relevant jurisprudence. For example, in the case of Jungelin vs Sweden, (CRPD Committee, 2011) the CRPD Committee had an opportunity to clarify the scope of reasonable accommodation under Art. 27 CRPD.

More broadly, if firm's primary stakeholder agendas differ from PWD concerns this indicates variations in degrees of legitimacy in what is regarded and respected as organizational policy, practice and initiatives towards the employability of PWDs. 
Thus, integrating PWD employment rises as a critical theme of firm sustainability strategy as focus of reporting practices. More meaningful key-performance indicators are warranted as a catalyst for endorsing greater quality reporting and practices as impactful non-discrimination policies for the workplace.

Voluntary reporting on disability employment should assist stakeholders in the appraisal on organizational non-financial performance in a coherent manner. This translates into robust data gathering mechanisms, explicit policies and concrete plans supported by well-aimed periodic disability-specific targets progress as well as indicators to track performance. To avoid duplication and ensure completeness, companies could utilize links in their sustainability reports to other corporate documents and/or sources where detailed PWD-related information can be available.

PWD employment may be considered an issue with varying materiality among companies as their impact depends on the industry they pertain to, their business model and the regulatory framework in place. Nevertheless, equal treatment and personalized management style are both material for all business entities regardless of size or type of activity.

With this in mind, managers should evaluate aspects of PWD rights with the highest relevance to their operation and devise formal reporting mechanisms to increase transparency and refine sustainability performance appraisal. In establishing their commitment to PWD employment companies should redefine their diversity management policies and social sustainability goals beyond the presumption that PWD rights are legally protected and therefore should be excluded or disregarded from reported issues. 
A policy implication for the purposes of this analysis is that measures towards achieving (and reporting on) disability diversity must be robustly underpinned by equality considerations. Art. 27 CRPD protects the right to equal access to employment. In this sense, corporate diversity policies and measures as well as reporting mechanisms must be enhanced, and clearly aim to foster and comprehensively inform on equality in employment for PWD. In the U.K. a gap remains between institutional rights and business practices with respect to inclusion of disabled people.

In line with previous studies (Hernandez et al., 2008; Segovia-San-Juan et al., 2017), our assessment demonstrates a certain need for more corporations that would act as 'disability champions' and who would more pro-actively advocate recruitment, hiring, continuance of employment as well as career advancement of people with disabilities. Such advocacy can be built around leadership programs for disability employment in collaboration with third sector organizations (charities, community groups, NGOs and social entrepreneurs) as well as opinion leaders who can collectively contribute to policy influence towards mainstreaming disability in the workplace and the labor market.

In the U.K., government has pursued austerity measures since the banking-crisis of 2007/8. This has particularly impacted local government budgets and services including Transportation, Health, Education, Housing, Care services / provisions and individual benefits such as Disability Living Allowances (DLA), Personal Independence Payments (PIP). At the same time, Job Centre support services have been criticized $-37 \%$ of disabled people believe firms will not hire them and PWDs 
apply for $60 \%$ more jobs than non-disabled people, all impacts of local government budget cuts of upto $40 \%$. Simply, the most vulnerable in society have been impacted - including disabled peoples. Most recently the UN inquiry into disability ruled that the government is failing and disability Minister Esther McVey has had to U-turn on a row over payments to people with mental health conditions, following a High Court ruling.

\section{Concluding remarks}

Future research could explore corporate PWD reporting in other national contexts drawing on the variety of institutional arrangements found in different regions and countries. This would allow comparative studies and theory-building on organizational accountability to PWD, shedding further light on drivers, motivational factors and organizational identities. Moving beyond published secondary data, the focus of our paper, researchers could employ qualitative interview approaches to reflect the differing viewpoints, attitudes or perceptions of employers, managers and individual PWDs (currently employed or seeking employment). Action research studies would frame enabling conditions, barriers or bottlenecks in the recruitment, selection, training and career advancement of PWD within the enterprise. In turn, such qualitative approaches would allow scholars to more rigorously document elements that influence the decision of a company to report on PWD employment and disclose relevant performance information. Ultimately, firms must better report and practice better engagement with this stakeholder group as a priority. 
What should annual corporate reports include to benefit raising profile for this group? Also how can learning environments support transition to employment for this group better? Can the social benefits system better support this group towards flexible employment and social integration opportunities? Implications for other countries or less regulated environments? Broader cultural factors e.g. impact on families.

\section{References}

Aguilera, R. V., Judge, W.J. and Terjesen, S.A., (2018) Corporate Governance Deviance ACADAMY of MANAGEMENT REV 2018 (online); 43:87-109 doi:10.5465/amr.2014.0394 Barnes, C. and Mercer, G., 2005. Disability, work, and welfare: challenging the social exclusion of disabled people. Work, employment and society, 19(3), pp.527-545.

Bradshaw, L. 2004. Integrating people with disabilities into the workplace. Durban Chamber of Commerce and Industry. Chamber Digest, 1(16), 9.

Brown, J. And Powell, A. (2018) People with Disabilities in employment. House of Commons Library Briefing Paper: Number 7540 published $8^{\text {th }}$ January 2018. Available at file:///C:/Users/user/Downloads/CBP-7540\%20(1).pdf accessed 19 ${ }^{\text {th }}$ January 2018.

Bruyere, S.M., 2000. Disability employment policies and practices in private and federal sector organizations. Employment and Disability Institute Collection, p.63.

Buciuniene, I. and Kazlauskaite, R. 2010. Integrating people with disability into the workforce: The case of a retail chain. Equality, Diversity and Inclusion: An International Journal, 29(5), 534-538

Cannon, M.D. and Edmondson, A.C. (2001) Confronting failure: antecedents and consequences of shared beliefs about failure in organizational work groups; Journal of Organizational Behavior 22 (2) : 161-17. Doi: 10.1002/Job.85.

Cornelius, N. and D. Skinner (2008). 'The careers of senior men and women: a capabilities theory perspective', British Journal of Management, 19, pp. S141-S149.

Deegan, C. 2002. The legitimising effect of social and environmental disclosures - A theoretical foundation. Accounting, Auditing and Accountability Journal, 15(3), 282-311.

Disability Living Foundation (2017) Key Facts. Available at http://www.dlf.org.uk/content/key-facts accessed 19th January 2018.

Disabled World (2018) Disability statistics : information, charts and tables. Available at https://www.disabled-world.com/disability/statistics/ accessed $19^{\text {th }}$ January 2018.

Donaldson, T. and Preston, L.E. 1995. The stakeholder theory of the corporation: Concepts, evidence, and implications. Academy of Management Review, 20(1), 65-91.

European Commission (EC). 2010. Europe 2020: A Strategy for smart, sustainable and inclusive growth. COM(2010) 2020 final, Brussels: European Commission.

European Network for Corporate Social Responsibility and Disability (CSR+D). 2012 Analysis of disability disclosure in CSR Reports. ONCE Foundation \& European Social Fund. Retrieved June 30, $2017 \quad$ https://csr-d.eu/wpcontent/uploads/Analysis of Disability Disclosure in Sustainability Etiquetado 11.pdf. 
Fasciglione, M. 2015. Article 27 of the CRPD and the Right of Inclusive Employment of People with Autism in Della Fina, V. (ed.) Protecting the Rights of People with Autism in the Fields of Education and Employment. Berlin: Springer.

Freeman, R.E. 1984. Strategic management: A stakeholder approach. Boston: Pitman.

French, E. (2001). 'Approaches to equity management and their relationship to women in management', British Journal of Management, 12, pp. 267-285.

Frooman, J. (1999). Stakeholder influence strategies. Academy of Management Review, 24(2), 191-205.

Global Reporting Initiative and ONCE Foundation. 2015. Disability in sustainability reporting. Global Reporting Initiative. Retrieved June 30, 2017 from https://www. globalreporting.org/resourcelibrary/GRI-y-Fundacion-ONCE-La-Discapacidad-en-lasMemorias-de-Sostenibilidad.pdf.

González, M. and Fernández, J. L. 2016. Consumers' loyalty related to labor inclusion of people with disabilities. Frontiers in Psychology, 7, doi: 10.3389/fpsyg.2016.00885

Goodpaster, K.E. 1991. Business ethics and stakeholder analysis. Business Ethics Quarterly, 1(1): 53-73.

Gray, R., Owen, D. and Maunders, K. 1987. Corporate social reporting: Accounting and accountability. Prentice-Hall International.

Habisch, A., Jonker, J., Wegner, M. and Schmidpeter, R. 2005. Corporate Social Responsibility Across Europe. Berlin: Springer.

Hartnett, H.P., Stuart, H., Thurman, H., Loy, B. and Batiste, L.C. 2011. Employers' perceptions of the benefits of workplace accommodations: Reasons to hire, retain and promote people with disabilities. Journal of Vocational Rehabilitation, 34(1), 17-23.

Hashim, J. and Wok, S. 2014. Predictors to employees with disabilities' organisational behaviour and involvement in employment. Equality, Diversity and Inclusion: An International Journal, 33(2), 193-209.

Hernandez, B., McDonald, K., Divilbiss, M., Horin, E., Velcoff, J. and Donoso, O. 2008 Reflections from employers on the disabled workforce: Focus groups with healthcare, hospitality and retail administrators. Employee Responsibilities and Rights Journal, 20, 157164.

Holvino, E. and Kamp, A. 2009. Diversity management: Are we moving in the right direction? Reflections from both sides of the North Atlantic. Scandinavian Journal of Management, 25, 395-403.

Houtenville, A. and Kalargyrou, V. 2012. People with disabilities: Employers' perspectives on recruitment practices, strategies, and challenges in leisure and hospitality. Cornell Hospitality Quarterly, 53(1), 40-52.

International Labour Office (ILO) 2010. Disability in the workplace: Company practices Working Paper No.3. Geneva: International Labour Office.

Kaye, S. 2010. The impact of the 2007-2009 recession on workers with disabilities. Monthly Labor Review, 133(10), 19-30.

Kayess, R. 2008. Out of Darkness into Light? Introducing the Convention on the Rights of Persons with Disabilities. Human Rights Law Review, 8(1), 1-34.

Klarsfeld, A., Ng E., Tatli, A (2012) Social regulation and diversity management: A comparative study of France, Canada and the UK. European Journal of Industrial Realtions vol. 18, (4) 309-327. Doi: $10.1177 / 0959680112461091$ 
Konrad, A.M., Moore, M.E., Doherty, A.J., Ng, E.S.W. and Breward, K. 2012. Vocational status and perceived well-being of workers with disabilities. Equality, Diversity and Inclusion: An International Journal, 31(2), 100-123.

Kulkarni, M. and Lengnick-Hall, M.L. 2014. Obstacles to success in the workplace for people with disabilities: A review and research agenda. Human Resource Development Review, 13(2), 158-180.

Kuznetsova, Y. and Yalcin, B. 2017. Inclusion of persons with disabilities in mainstream employment: is it really all about the money? A case study of four large companies in Norway and Sweden. Disability \& Society, 32(2), 233-253.

Lambert, M. (2017) Austerity has trampled over disabled peoples rights. But the U.K. wont admit it. Published in the Guardian $4^{\text {th }}$ September 2017. Available at https://www.theguardian.com/commentisfree/2017/sep/04/austerity-disabled-people-rightsuk-un-government accessed 19th January 2018.

Lengnick-Hall, M. 2007. Hidden Talent: How Leading Companies Hire, Retain, and Benefit from People with Disabilities. Westport: Greenwood Publishing Group.

Lindblom, C. K. 1994. The implications of organizational legitimacy for corporate social performance and disclosure. New York: Critical perspectives on accounting conference.

Mackelprang, R.W. and Salsgiver, R., 2016. Disability: A diversity model approach in human service practice. Oxford University Press.

Markel, K. S. and Barclay, L.A. 2009. Addressing the underemployment of persons with disabilities: Recommendations for expanding organizational social responsibility. Employee Responsibilities and Rights Journal, 21(4), 305-318.

Mathews, M.R. 1993. Socially responsible accounting. CRC Press.

Min-Young, L., Fairhurst, A. and Wesley, S. 2009. Corporate social responsibility: A review of the Top 100 US retailers. Corporate Reputation Review, 12, 140-158.

Office for Disability Issues. 2008. Independent Living: A Cross-Government Strategy about Independent Living for Disabled People. London: Office for Disability Issues.

Office for Disability Issues. 2009. Roadmap 2025: Achieving disability equality by 2025 London: Office for Disability Issues.

Oliver, M. (1996) Understanding Disability: from theory to practice. MacMillan, Basingstoke.

Oreg, S., Bartunek, J.M., Lee, G. and Do, B., (2018) An Affect-Based Model of Recipients'

Responses to Organizational Change Events available online at ACAD MANAGE REV

2018; 43:65-86 doi:10.5465/amr.2014.0335

Organisation for Economic Co-operation and Development (OECD). 2010. Sickness, disability and work: breaking the barriers. A synthesis of findings across OECD countries. Paris: OECD Publishing.

Organisation for Economic Co-operation and Development (OECD). 2012. Equity and quality in education: Supporting disadvantaged students and schools. Paris: OECD Publishing.

Özbilgin, M. and Tatli, A., 2011. Mapping out the field of equality and diversity: Rise of individualism and voluntarism. human relations, 64(9), pp.1229-1253.

Papworth Trust (2016) Disability in the United Kingdom : Facts an Figures. Available at http://www.papworthtrust.org.uk/sites/default/files/Disability\%20Facts\%20and\%20Figures\% 202016.pdf accessed $19^{\text {th }}$ January 2018. 
Peloza, J. and Shang, J. 2011. How can corporate social responsibility activities create value for stakeholders? A systematic review. Journal of Academy of Marketing Science, 39, 117135.

Pérez, F.J., Romeo, M. and Yepes-Baldó, M., 2017. The corporate social responsibility policies for the inclusion of people with disabilities as predictors of employees' identification, commitment and absenteeism. Anales de Psicología/Annals of Psychology, 34(1), pp.101-107.

Priestley, M., 2007. In search of European disability policy: between national and global. ALTER-European Journal of Disability Research/Revue Européenne de Recherche sur le Handicap, 1(1), pp.61-74.

Priestley, M. (1998) Constructions and creations: idealism, materialism and disability theory. Disability \& Society, 13 (1) (1998), pp. 75-94

Quinn, G. 2009. The United Nations Convention on the Rights of Persons with Disabilities: Toward a new international politics of disability. Texas Journal on Civil Liberties \& Civil Rights, 15, 33-53.

Roberts, R.W. 1992. Determinants of corporate social responsibility disclosure: An application of stakeholder theory. Accounting, Organizations and Society, 17(6), 595-612.

Romañach, J. and Lobato, M. 2005. Functional diversity, a new term in the struggle for dignity in the diversity of the human being. Spain: Independent Living Forum.

Ryan, M. K. and S. A. Haslam (2009). 'Glass cliffs are not so easily scaled: on the precariousness of female CEOs' positions', British Journal of Management, 20, pp. 13-16.

Sainsbury, R. 2011. Policies for promoting labour market participation of persons with disabilities in Europe and USA. York: Social Policy Research Unit, University of York.

Samant, D., Soffer, M., Hernandez, B., Adya, M., Akinpelu, O., Levy, J.M., Repoli, E., Kramer, M. and Blanck, P. 2009. Corporate culture and employment of people with disabilities: role of social workers and service provider organizations. Journal of Social Work in Disability \& Rehabilitation, 8(3-4), 171-188.

Samoy, E. 2010. Policies for promoting labour market participation of persons with disabilities in Europe and USA. Belgium: Department of Work and Social Economy of the Flemish Community.

Schur, L., Kruse, D. and Blanck, P., 2005. Corporate culture and the employment of persons with disabilities. Behavioral Sciences \& the Law, 23(1), pp.3-20.

Segovia-San-Juan, A. I., Saavedra, I. and Fernández-de-Tejada, V. 2017. Analyzing Disability in Socially Responsible Companies. Social Indicators Research, 130(2), 617-645.

Shepherd, D.A. and Williams, T.A. (2018) Hitting Rock Bottom After Job Loss: Bouncing Back to Create a New Positive Work Identity. Available online at ACAD MANAGE REV 2018; 43:28-49 doi:10.5465/amr.2015.0102

Suchman, M.C. 1995. Managing legitimacy: Strategic and institutional approaches. Academy of Management Review, 20(3), 571-610.

Tatli, A., 2011. A multi- layered exploration of the diversity management field: diversity discourses, practices and practitioners in the UK. British Journal of Management, 22(2), pp.238-253.

Tatli, A., V, J., Ariss, A.A. and Özbilgin, M., 2012. The role of regulatory and temporal context in the construction of diversity discourses: The case of the UK, France and Germany. European Journal of Industrial Relations, 18(4), pp.293-308. 
Tatli, A. and M. Ozbilgin (2009). 'Understanding diversity managers' role in organizational change: towards a conceptual framework', Canadian Journal of Administrative Sciences, 26, pp. 244-258.

Vauclair, C.M. and Fischer, R. 2011. Do cultural values predict individual's moral attitudes? A cross-cultural multi level approach. European Journal of Social Psychology, 44, 645-657.

United Nations (UN). 2006. Convention on the Rights of Persons with Disabilities. New York: General Assembly United Nations.

United Nations (UN). 2017. UN Enable: Factsheet on Persons with Disabilities. https://www.un.org/development/desa/disabilities/resources/factsheet-on-persons-withdisabilities.html. Accessed on 14 June 2017.

United Nations Committee on the Rights of Persons with Disabilities, 2011. Jungelin $v$ Sweden, CRPD/C/12/D/5/2011. Retrieved October 10, 2017, http://docstore.ohchr.org/SelfServices/FilesHandler.ashx?enc=6QkG1d\%2fPPRiCAqhKb7y hsmRI\%2fAQgnMbJPLLbuFnLlB9VQPlQbxtBIWbTkFILiZcGyszPXoVCvdvyyRKkqaul5 gr37TDGt13qZTxDa9Nz0OyUZ2X17gbvYGahRNrDQ5WVsbuGAY3bTzgO9a1Ax2o\%2b $\underline{X g} \% 3 \mathrm{~d} \% 3 \mathrm{~d}$

United Nations Committee on the Rights of Persons with Disabilities, 2017. Concluding Observations on the Report of the United Kingdom of Great Britain and Northern Ireland. Geneva: United Nations.

United Nations Human Rights Council (UNHRC). 2011. Guiding Principles on Business and Human Rights. Geneva: General Assembly United Nations.

United Nations Human Rights Council (UNHRC). 2012. The Corporate Responsibility to Protect Human Rights. Geneva: United Nations.

Vale, J. (2018) Majority of Disability benefit claimants being left with not enough to live on, campaigners warn. The Independent $18^{\text {th }}$ January 2018 available at: http://www.independent.co.uk/news/uk/politics/disability-benefit-claimants-insufficientfunds-employment-support-allowance-survey-labour-a8163576.html accessed 09th February 2018.

Waxman D. 2017. Model of successful corporate culture change integrating employees with disabilities, in B.M. Altman (ed.) Factors in Studying Employment for Persons with Disability (Research in Social Science and Disability, V.10) Emerald Publishing Limited, pp.155-180

Williams, B.R. 2017. Disability in the Australian workplace: corporate governance or CSR issue?. Equality, Diversity and Inclusion: An International Journal, 36(3), 206-221.

World Bank (2018) Global Partnership for Education : Children with Disabilities. Available at https://www.globalpartnership.org/focus-areas/children-with-disabilities accessed 19th January 2018.

World Health Organization (WHO). 2011. World Report on Disability. Geneva: World Health Organization.

Zanoni, P. and M. Janssens (2007). 'Minority employees engaging with (diversity) management: an analysis of control, agency and micro-emancipation', Journal of Management Studies, 44, pp. 1371-1397 